\title{
STRATEGI PENGEMBANGAN BISNIS PROPERTI UNTUK KAWASAN CENGKARENG BUSINESS CITY
}

\author{
Henri Suharlim
}

Fakultas Ekonomi, Universitas Tarumanagara Jakarta

Email: heinreich15967@gmail.com

\begin{abstract}
ABSTRAK
Pertumbuhan besar pembangunan real estate di Jakarta terutama di dekat Bandara Internasional Soekarno-Hatta dan pertumbuhan pesat kondisi ekonomi Indonesia karena program tax amnesty yang diadakan oleh pemerintah, harus meningkatkan peluang bagi perusahaan pengembang real estate lokal dan internasional. Business plan ini akan memberikan informasi dan konsep dasar yang diperlukan oleh ahli strategi bisnis atau investor dalam mengevaluasi kelayakan aspek dan sebagai pedoman dan informasi strategis untuk manajer berikutnya yang mencoba mengembangkan konsep bisnis konstruksi yang sesuai di Cengkareng, Jakarta Barat yang merupakan lokasi yang dekat dengan bandara internasional. Konsep bisnis ini bertujuan untuk menjadi konsep dasar bagi pemasar dan ahli strategi bisnis di Kota Bisnis Cengkareng (CBC) untuk membangun kembali area situs kosong menjadi produk bangunan yang sesuai dan menguntungkan bagi investor dengan memberikan informasi, perhitungan, dan konsep desain yang berguna untuk selanjutnya proyek dalam CBC. Berdasarkan hasil studi kelayakan rencana bisnis, rencana bisnis ini dihitung untuk mencapai hasil yang baik untuk investasi dengan mendapatkan nilai NPV sebesar Rp 219.556.798.184,16, dengan menggunakan asumsi biaya modal 10\%. Ia juga berencana untuk mendapatkan nilai IRR 30\%, lebih besar dari tingkat tahunan 10\%. Ini menunjukkan bahwa investasi untuk business plan ini dapat melebihi tingkat investasi yang ditujukan oleh investor $\mathrm{CBC}$ sendiri.
\end{abstract}

Kata Kunci: business plan, konstruksi, desain bangunan dan konsep, aerotropolis, studi kelayakan

\begin{abstract}
The massive growth of real estate development in Jakarta especially in near area Soekarno-Hatta International Airport and rapid growth Indonesia economic condition due to tax amnesty program that held by government, should increase opportunity for the local and international real estate developer company. This business plan will provide the information and basic concept that needed by business strategist or investors in evaluating aspect feasibility and as guidelines and strategic information for next managers who try to develop suitable construction business concept in Cengkareng, West jakarta which is the location itself near with international airport.This business concept aim to become basic concept for the marketers and business strategist in Cengkareng Business City $(C B C)$ to redeveloped blank site area into suitable and profitable building product for the investors by providing useful information, calculation, and design concept for next project in CBC. Based on result of business plan feasibility study, this business plan is calculated to achieve good results for investment by gaining NPV value of $R p$ 219,556,798,184.16, by using assumption cost of capital 10\%. It also planned to gain IRR value $30 \%$, it bigger than yearly rate 10\%. It shows that the investment for this business plan can exceed the rate of investment that aimed by $C B C$ investors themselves.
\end{abstract}

Keywords: business plan, construction, design buildings and concept, aerotropolis, feasibility study

\section{PENDAHULUAN Latar Belakang}

Kawasan di sekeliling Bandara Soekarno-Hatta, Tangerang, Banten, kini menjadi salah satu sentra baru pengembangan properti di Jabodetabek. Selain meladeni kebutuhan hunian karyawan yang bekerja di bandara yang terus meningkat seiring dengan makin banyaknya maskapai penerbangan yang singgah di terminal pesawat terbesar di Indonesia itu, juga untuk memenuhi kebutuhan hunian mereka yang sehari-hari beraktifitas di Jakarta Barat dan Tangerang . Melihat tren perkembangan properti saat ini yang mulai mengarah ke daerah sekitar bandara. Pusat kota kini tidak lagi menjadi satu-satunya kawasan yang diincar untuk perluasan bisnis para pengembang. 
Orientasi sudah bergeser ke kawasan alternatif, terutama area di sekitar bandar udara (Bandara). Fenomena ini menyebabkan evolusi baru dalam ilmu tata kota dan pengembangan bisnis real estate, dimana terciptanya kota bandara yang merupakan penggabungan antara perencanaan bandara, perencanaan tata kota, pengembangan lokasi bisnis untuk perencanaan kota yang ekonomis, efisien, berkembang dan dinamis .

Developer Cengkareng Business City selaku salah satu developer di kawasan sekitar bandara melihat peluang tersebut. Area tersebut dibangun sebagai support HUB terhadap airport. Integrasi kawasan yang menunjang bandara seperti kawasan mixed use area yang bertemakan SCBD, jembatan penghubung Rawa Bokor ke Dadap yang melintangi jalan tol Prof.Sedyatmo dan pembangunan jalan tol di dalam kawasan sebagai akses langsung ke tol bandara. Area yang seluas $38 \mathrm{Ha}$ dibagi menjadi 10 blok dan masing-masing blok terhubung dengan tunnel underground sehingga tidak mengganggu akses tol ke Bandara dan Serpong.

Permasalahan yang ada dan sedang dialami oleh perusahaan $\mathrm{CBC}$ adalah kurang matangnya konsep bisnis yang akan diterapkan. Dengan lahan seluas $38 \mathrm{Ha}$ dengan akses yang sangat dekat dengan Bandara Soekarno Hatta, perusahaan ini kesulitan melahirkan inovasi produk dan gagasan konsep kawasan CBC. Hal ini dapat terlihat dari sulitnya mengambil keputusan yang terlihat dari perkembangan masterplan di bawah ini dimana masterplan CBC terus berubah rubah dan hingga akhirnya terdapat area LOT yang dikosongkan.

Tidak matangnya konsep bisnis dan masterplan untuk kawasan CBC, menyebabkan beberapa persoalan:

1. Infrastruktur yang sudah berjalan ataupun sudah jadi di lapangan yang mengacu pada konsep awal, terpaksa harus dibongkar atau pun di renovasi lagi . Hal ini merupakan pemborosan dari segi biaya dan waktu

2. Sering terjadi bongkar - pasang instalasi mechanical - electrical - plumbing, seperti bongkar pasang saluran kawasan - bongkar pasang lnstalasi lampu PJU karena ketidak pastian masterplan

Masih banyak lahan kosong di kawasan CBC, sehingga menimbulkan kesan kawasan ini merupakan proyek yang mangkrak, padahal tidak. Terkadang ada beberapa penghuni gedung di kawasan CBC yang komplain karena lingkungan CBC yang terkesan "proyek mati suri".

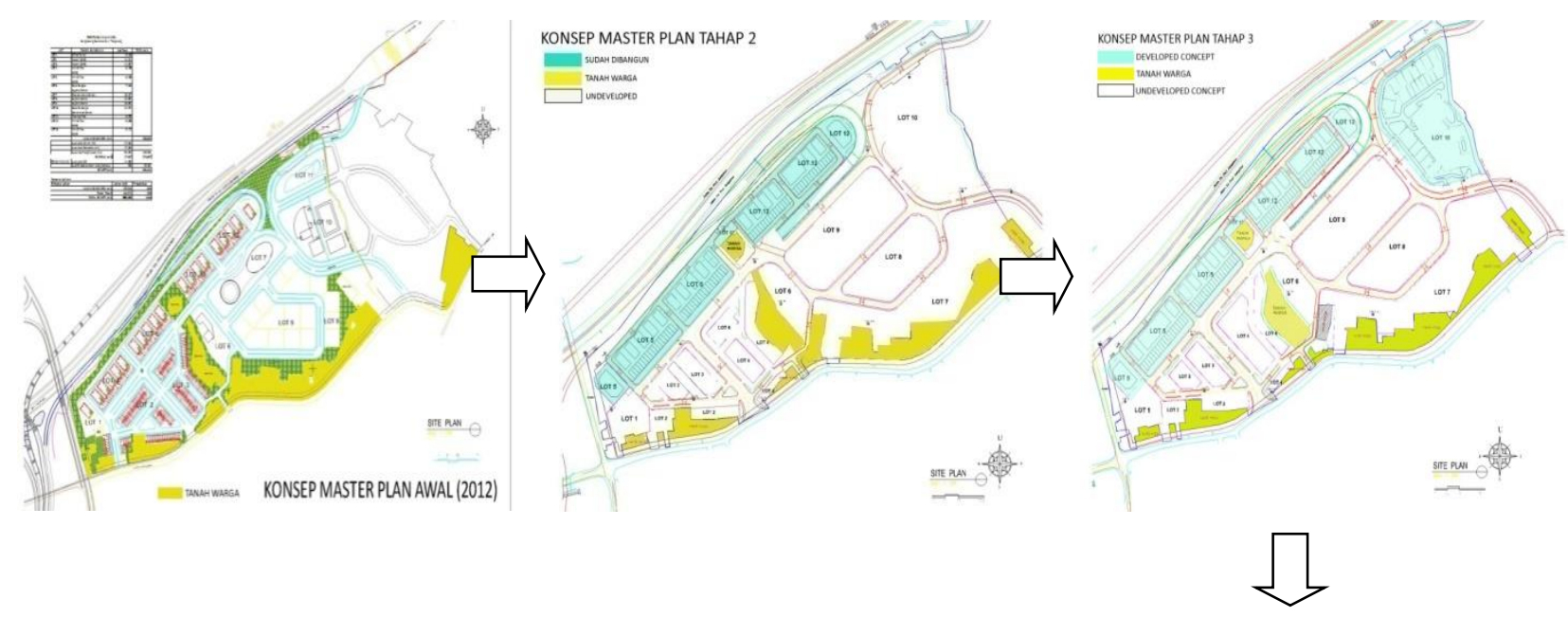




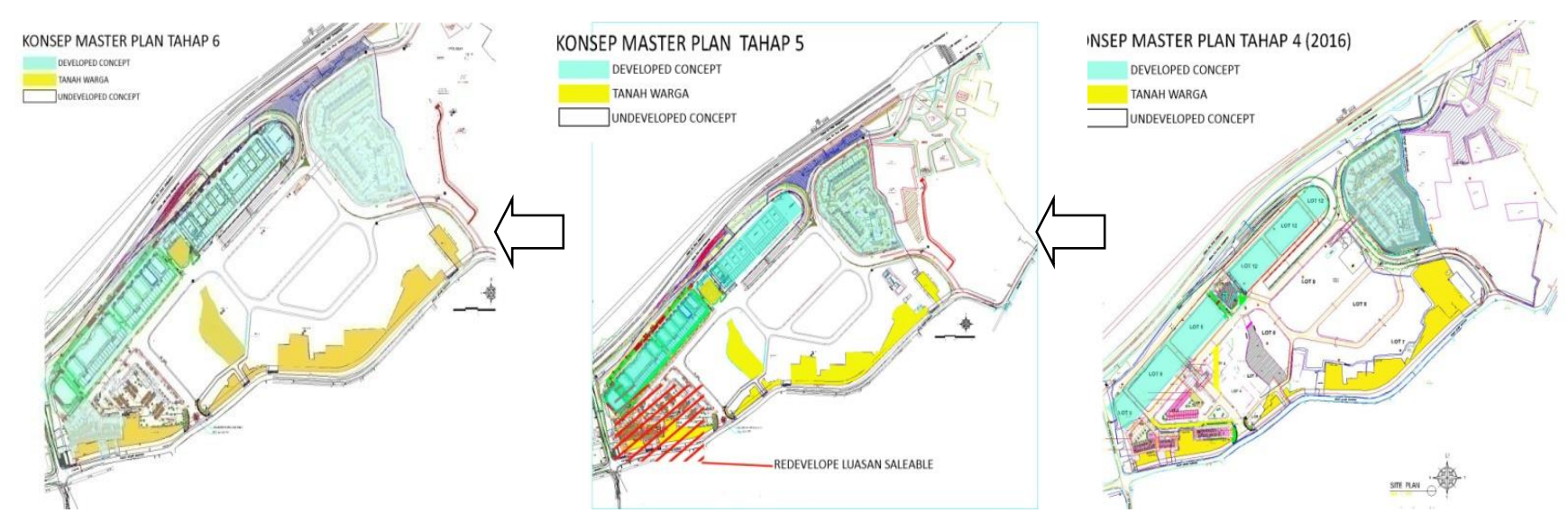

\section{METODE PENELITIAN}

Metode penelitian yang dipakai untuk penelitian ini memakai metode dengan pendekatan deskripsi secara sistematis, faktual, dan akurat mengenai fakta dan sifat populasi atau daerah tertentu dan mempelajari secara intensif latar belakang keadaan sekarang (deskriptif) dan interaksi lingkungan suatu obyek (studi kasus) . Dengan mempelajari kondisi proyek eksisting termasuk interaksi proyek terhadap lingkungan, infrastruktur yang ada, kondisi sosial, maupun karakteristik pembeli di kawasan ini. Data - data yang diperoleh penulis sebagai dasar penelitian ini adalah pengamatan langsung di lapangan terkait kondisi proyek, dan data sertifikat layak fungsi yang telah diajukan ke Pemda Tangerang.

Selain itu juga studi literatur yang berhubungan dengan penelitian ini yakni teori arsitektur teori perkotaan - teori marketing - teori manajemen konstruksi - dan teori manajemen strategik. Dari data - data yang telah diperoleh, kemudian diolah lagi dengan metode penelitian tindakan yang bertujuan untuk mengembangkan keterampilan baru atau pendekatan baru dan diterapkan langsung serta dikaji hasilnya.

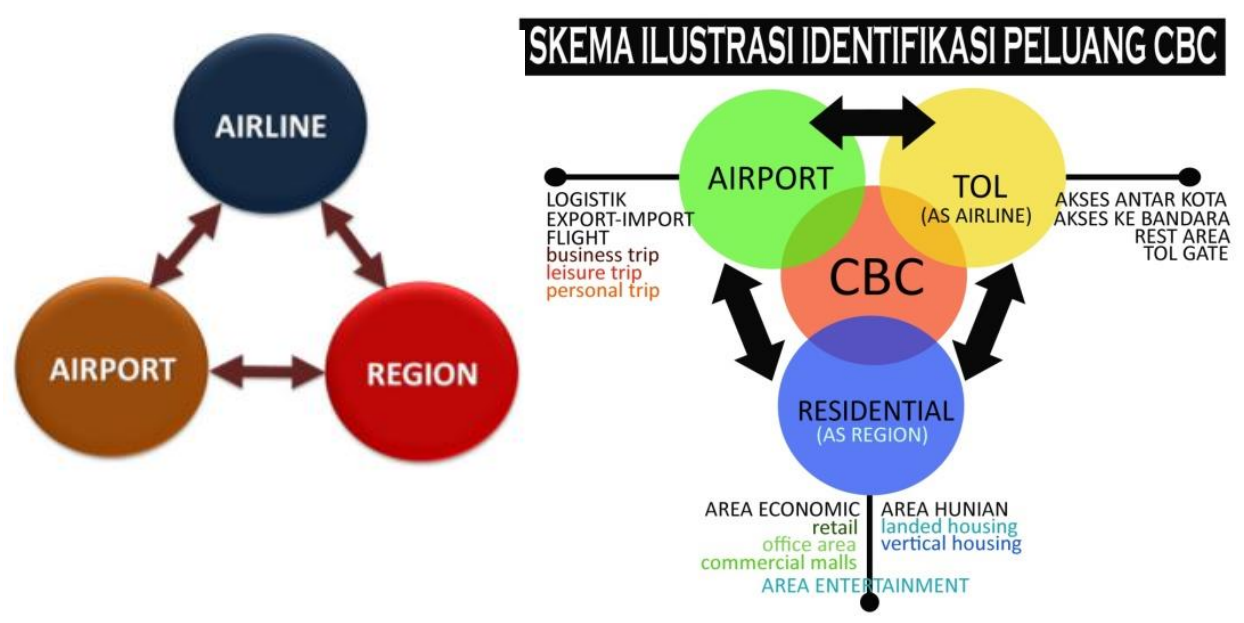

Area yang diteliti adalah area lot 8 dan lot 9 karena area tersebut memiliki lokasi yang sangat strategis dibandingkan area lain. Area tersebut berada di tengah kawasan dan memiliki akses langsung ke jalan primer kawasan. Tujuannya adalah untuk menentukan konsep bisnis potensial yang akan dibangun untuk area lot 8 dan lot 9 . 


\section{HASIL DAN PEMBAHASAN}

Menurut penulis, untuk pengisian LOT 8 dan LOT 9 untuk next project, dapat dikembangkan dengan memilih alternative 1 yakni konsep rental apartemen LOFTS + retail area + terminal shuttle bus. Alasan penulis lebih memilih alternatif 1 daripada alternatif 2 adalah:

- Ada kompetitor lain yakni Intiland yang mengembangkan konsep apartemen sewa yakni aeropolis dan terbukti sold out

- Sudah jelas ada peminatnya, yakni para pekerja kawasan bandara dan perusahaan maskapai penerbangan

- Investasi yang dikeluarkan jauh lebih sedikit daripada investasi untuk alternatif 2

- Pengurusan ijin infrastruktur kawasan LOT 8 dan LOT 9 lebih sedikit daripada alternative 2

- $\quad$ CBC sudah memiliki pengalaman di bidang apartemen dan retail, dan sudah menunjuk operator traffic kawasan CBC yakni Secure Parking

\section{ALTERNATIF 1. LOFTS apartment with retail + terminal support}

\begin{tabular}{|c|c|c|}
\hline No & Kelebihan & Kelemahan \\
\hline 1 & $\begin{array}{l}\text { Jumlah occupancy lebih besar dari } \\
\text { pada alternatif } 2\end{array}$ & $\begin{array}{l}\text { Penjualan memakai model sewa, jadi durasi } \\
\text { untuk balik modal lebih lama daripada direct } \\
\text { sell }\end{array}$ \\
\hline 2 & $\begin{array}{l}\text { Sudah jelas ada peminatnya, } \\
\text { khususnya untuk apartemen yakni } \\
\text { perusahaan maskapai penerbangan } \\
\text { dan hotel }\end{array}$ & $\begin{array}{l}\text { Memerlukan investasi yang besar dulu, } \\
\text { terutama dalam maintenance, security karena } \\
\text { bersifat sewa }\end{array}$ \\
\hline 3 & $\begin{array}{l}\text { Selama bandara masih beroperasi, } \\
\text { maka apartemen tetap ada } \\
\text { peminatnya,khususnya dari para } \\
\text { pekerja daerah bandara }\end{array}$ & $\begin{array}{l}\text { Wajib menyiapkan tenaga ahli / teknisi } \\
\text { khususnya dalam hal maintenance bangunan } \\
\text { terutama sistem mekanikal - elektrikal }\end{array}$ \\
\hline 4 & $\begin{array}{l}\text { Apabila apartemen terisi sebagai } \\
\text { hunian, maka otomatis area retail juga } \\
\text { akan terisi }\end{array}$ & $\begin{array}{l}\text { Menyiapkan sistem parkir terpadu karena } \\
\text { konsep kawasan dengan Lot yang terintegrasi }\end{array}$ \\
\hline 5 & $\begin{array}{l}\text { Membantu menghidupkan area } \\
\text { komersial CBC di lot lainnya } \\
\text { terutama LOT } 10, \text { rencana akan } \\
\text { dibangun mall }\end{array}$ & $\begin{array}{l}\text { Wajib menyiapkan cadangan lahan kosong, } \\
\text { baik lahan terbuka maupun bangunan } \\
\text { berstruktur untuk antisipasi kuota parkir }\end{array}$ \\
\hline 6 & $\begin{array}{l}\text { Konsep terminal shuttle bus bandara - } \\
\mathrm{CBC} \text { akan berjalan karena didukung } \\
\text { rencana } \mathrm{CBC} \text { akan menjadi area } \\
\text { lounge dan penjualan tiket bagi calon } \\
\text { penumpang }\end{array}$ & $\begin{array}{l}\text { Perlu memperhatikan dan mematangkan } \\
\text { sistem traffic kawasan karena kawasan CBC } \\
\text { integrated dengan jalur tol, jalan primer } \\
\text { Atang Sanjaya dan traffic internal kawasan }\end{array}$ \\
\hline
\end{tabular}




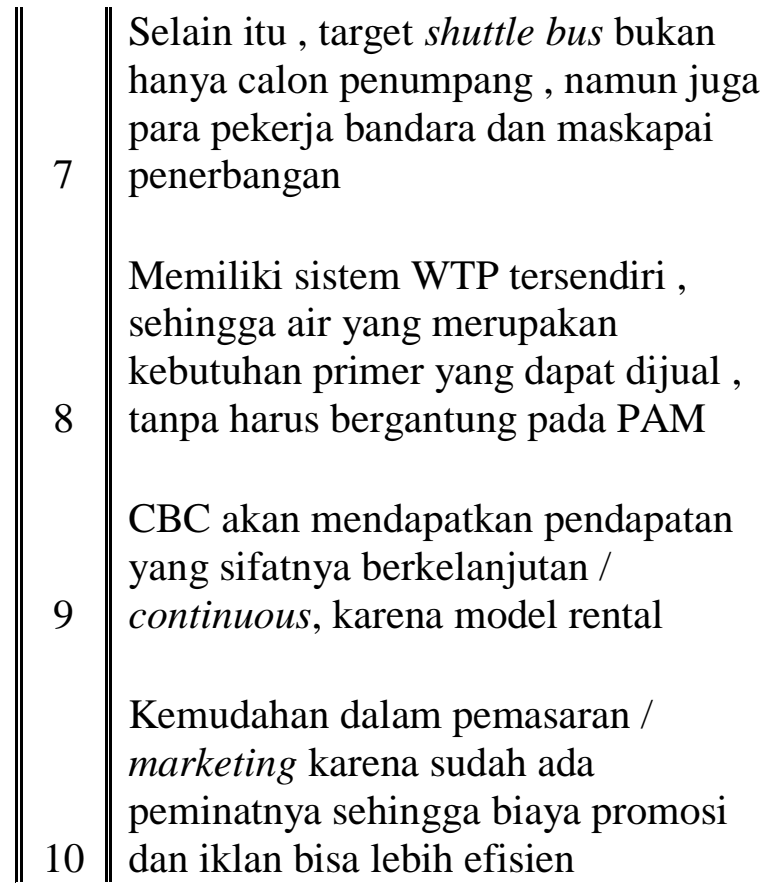

Supply air bersih bergantung pada WTP Kawasan maka perlu ekstra dalam control maintenance termasuk investasi instalasi di kemudian hari

- Jumlah unit room apartemen $=96$ unit ( luas per unit $=7.5 \times 5+5 \times 5=62.5 \mathrm{sqm}$ )

- Luas total area hunian $=6000 \mathrm{sqm}$, luas total koridor $=85 \mathrm{x} 4$ lantai $\mathrm{x} 7$ tower $=2380 \mathrm{sqm}$. open space for parking $=6200 \mathrm{sqm}$, dengan luas 1 mobil $=12.5 \mathrm{sqm}$ maka mampu menampung 500 mobil . Area komersial di apartemen : $10 \times 12$ x 3 lantai $\times 4$ tower $=1440 \mathrm{sqm}$.

- Luas area terminal $=135 \times 27+25 \times 27=4300$ sqm

- Luas area komersial $=130 \times 35+20 \times 40=5350 \times 2$ lantai $=10700 \mathrm{sqm}$.

- Luas area parkir area komersial + terminal = 5300 sqm ( 420 mobil + 25 bus ukuran besar @ $2.5 \times 12 \mathrm{~m})$.

\section{ELEMENTAL COST ESTIMATE}

\section{PROYEK : APARTEMEN+KOMERSIAL+TERMINAL DI LOT 8+LOT 9}

\begin{tabular}{|c|c|c|c|c|c|c|c|c|c|}
\hline NO. & $\begin{array}{l}\text { URAIAN } \\
\text { PEKERJAAN }\end{array}$ & $\begin{array}{l}\text { Luas } \\
\text { Gross }\end{array}$ & $\begin{array}{c}\text { A - } \\
\text { PEKERJAAN } \\
\text { STRUKTUR }\end{array}$ & Harga/m2 & $\begin{array}{c}\text { B - } \\
\text { PEKERJAAN } \\
\text { FINISHING }\end{array}$ & Harga/m2 & $\begin{array}{c}\text { C- } \\
\text { PEKERJAAN } \\
\text { M/E }\end{array}$ & Harga/m2 & TOTAL \\
\hline I & $\begin{array}{l}\text { RETAINING } \\
\text { SYSTEM }\end{array}$ & tidak ada & tidak ada & tidak ada & tidak ada & tidak ada & tidak ada & & tidak ada \\
\hline II & PONDASI & 14340.00 & $29,927,580,000$ & $2,087,000$ & tidak ada & tidak ada & tidak ada & tidak ada & $29,927,580,000$ \\
\hline III & BASEMENT & tidak ada & tidak ada & tidak ada & tidak ada & tidak ada & tidak ada & tidak ada & tidak ada \\
\hline
\end{tabular}




\begin{tabular}{|c|c|c|c|c|c|c|c|c|c|}
\hline IV & APARTMENT & 8380.00 & $9,663,430,520$ & $1,153,154$ & $20,489,519,000$ & $2,445,050$ & $17,424,408,300$ & $2,079,285$ & $47,577,357,820$ \\
\hline $\mathrm{V}$ & KOMERSIAL & 12140.00 & $13,999,289,560$ & $1,153,154$ & $29,682,907,000$ & $2,445,050$ & $25,242,519,900$ & $2,079,285$ & $68,924,716,460$ \\
\hline VI & $\begin{array}{l}\text { TERMINAL } \\
\text { SHUTTLE }\end{array}$ & 4300.00 & $4,958,562,200$ & $1,153,154$ & $1,451,250,000$ & 337,500 & $4,300,000,000$ & $1,000,000$ & $10,709,812,200$ \\
\hline \multicolumn{2}{|r|}{$\begin{array}{l}\text { PEKERJAAN } \\
\text { LUAR }\end{array}$} & 11500.00 & $11,500,000,000$ & $1,000,000$ & $17,850,576,000$ & $1,552,224$ & $2,423,582,536$ & tidak ada & $31,774,158,536$ \\
\hline & SUB TOTAL : 1 & & $70,048,862,280$ & $1,382,725$ & & $1,371,383$ & & 974,941 & $188,913,625,016$ \\
\hline & PRELIMINARIES & & $\begin{array}{l}4,814,553,874 \\
\text { (12\% Diluar } \\
\text { Pondasi) }\end{array}$ & & $\begin{array}{c}5,557,940,160 \\
(8 \%)\end{array}$ & & $\begin{array}{c}2,469,525,537 \\
(5 \%)\end{array}$ & & $12,842,019,570$ \\
\hline & SUB TOTAL : 2 & \multirow{3}{*}{$5.0 \%$} & $74,863,416,154$ & $1,477,762$ & $75,032,192,160$ & $1,481,093$ & $51,860,036,273$ & $1,023,688$ & $201,755,644,586$ \\
\hline & CONTIGENCY & & $3,743,170,808$ & & $3,751,609,608$ & & $2,593,001,814$ & & $10,087,782,229$ \\
\hline & & & & & & & & & $211,843,426,816$ \\
\hline & DIBULATKAN & Rp. & 78,606,587,000 & & 78,783,802,000 & & $54,453,038,000$ & & $211,843,427,000$ \\
\hline & Harga Per M2 & Rp. & $1,551,650$ & & $1,555,148$ & & $1,074,872$ & & $4,181,670$ \\
\hline & $\begin{array}{l}1 \text { USD = } \\
\text { Rp.13.500,- }\end{array}$ & USD & 115 & & 115 & & 80 & & 310 \\
\hline
\end{tabular}

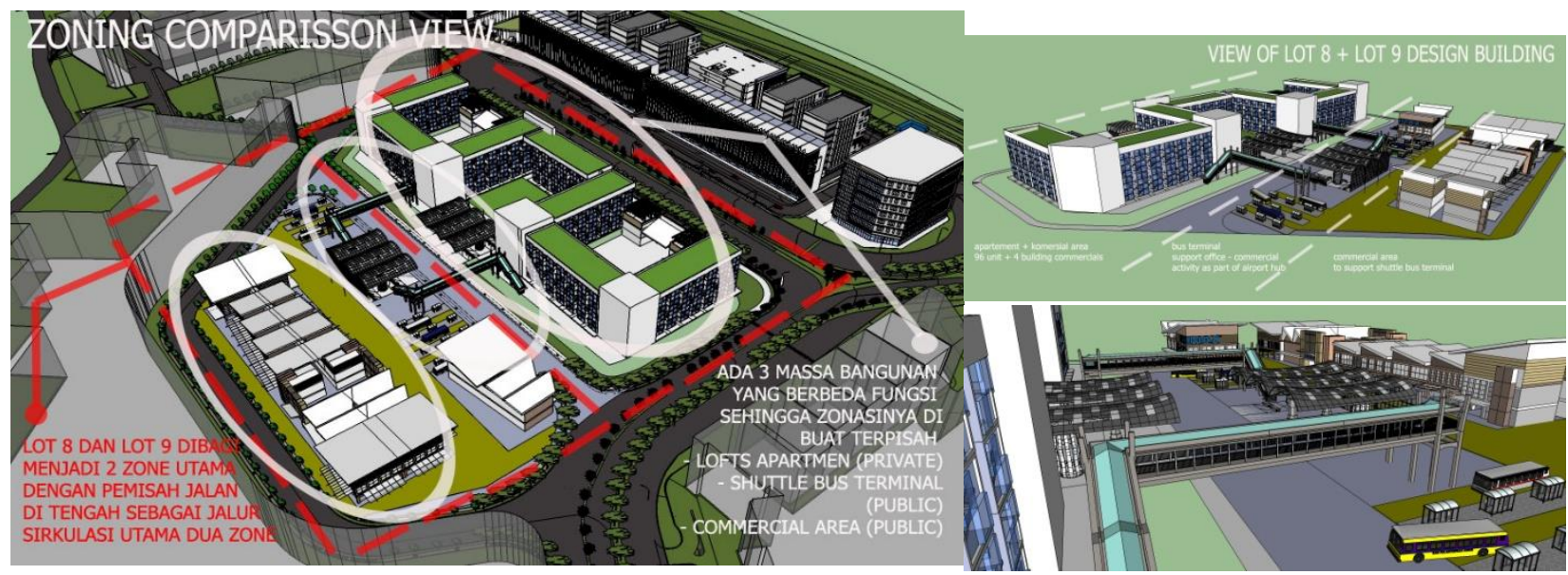




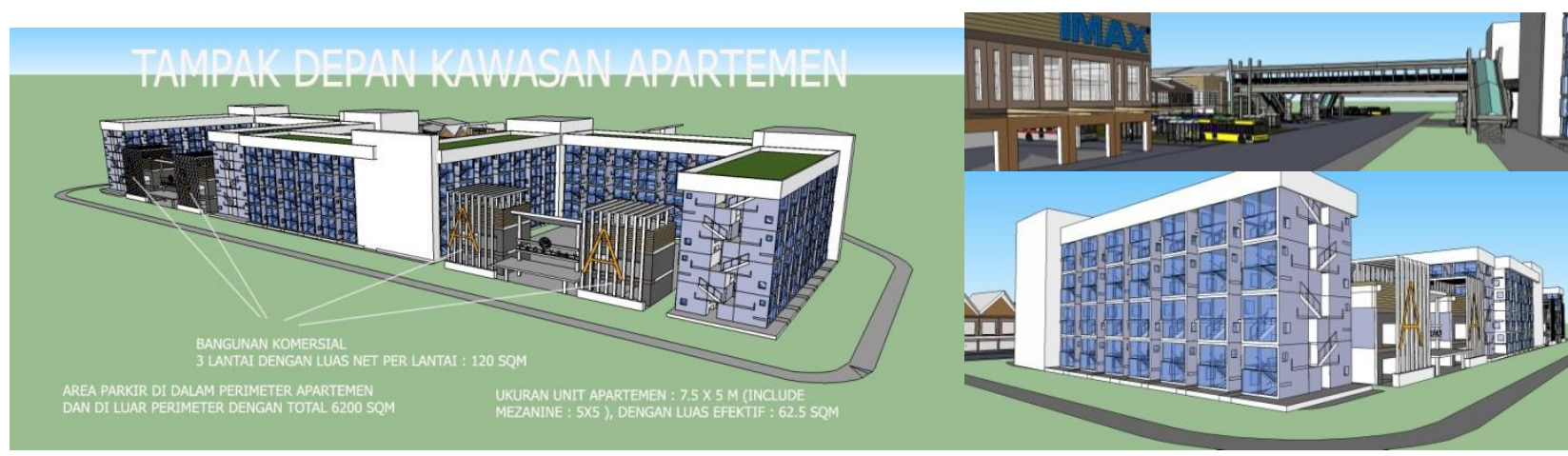

Dari elemental cost proyek yang ada, dapat dilihat bahwa persentasi struktur lebih tinggi , disusul arsitektur dan ME ( note arsitektur dan ME memiliki nilai yang hamper mirip karena proyek yang sedang berjalan membangun hotel lengkap dengan interior - furniture nya ).

Karena sudah diketahui biaya struktur memiliki nilai tertinggi, maka untuk menekan biaya konstruksi awal dan memudahkan marketing untuk menentukan nilai sewa dan biaya operasional dan maintenance ke depannya maka :

- Apartemen dibuat model loft, karena dengan model loft dapat menghemat pekerjaan struktur sebesar 30-40\%

- Apartemen dibuat tanpa basement untuk menghindari biaya structural basement dan galian tanah, komposisi pekerjaan basement memiliki komposisi sebesar 50\% dari nilai pekerjaan struktur keseluruhan gedung .

- Untuk terminal dan komersial dibuat dengan konsep terbuka, dengan tujuan meminimalisir pemakaian material arsitektur, dan memberi kebebasan bagi para penyewa untuk mengolah ruang sewa di kawasan komersial.

\section{ASUMSI PERHITUNGAN PENDAPATAN}

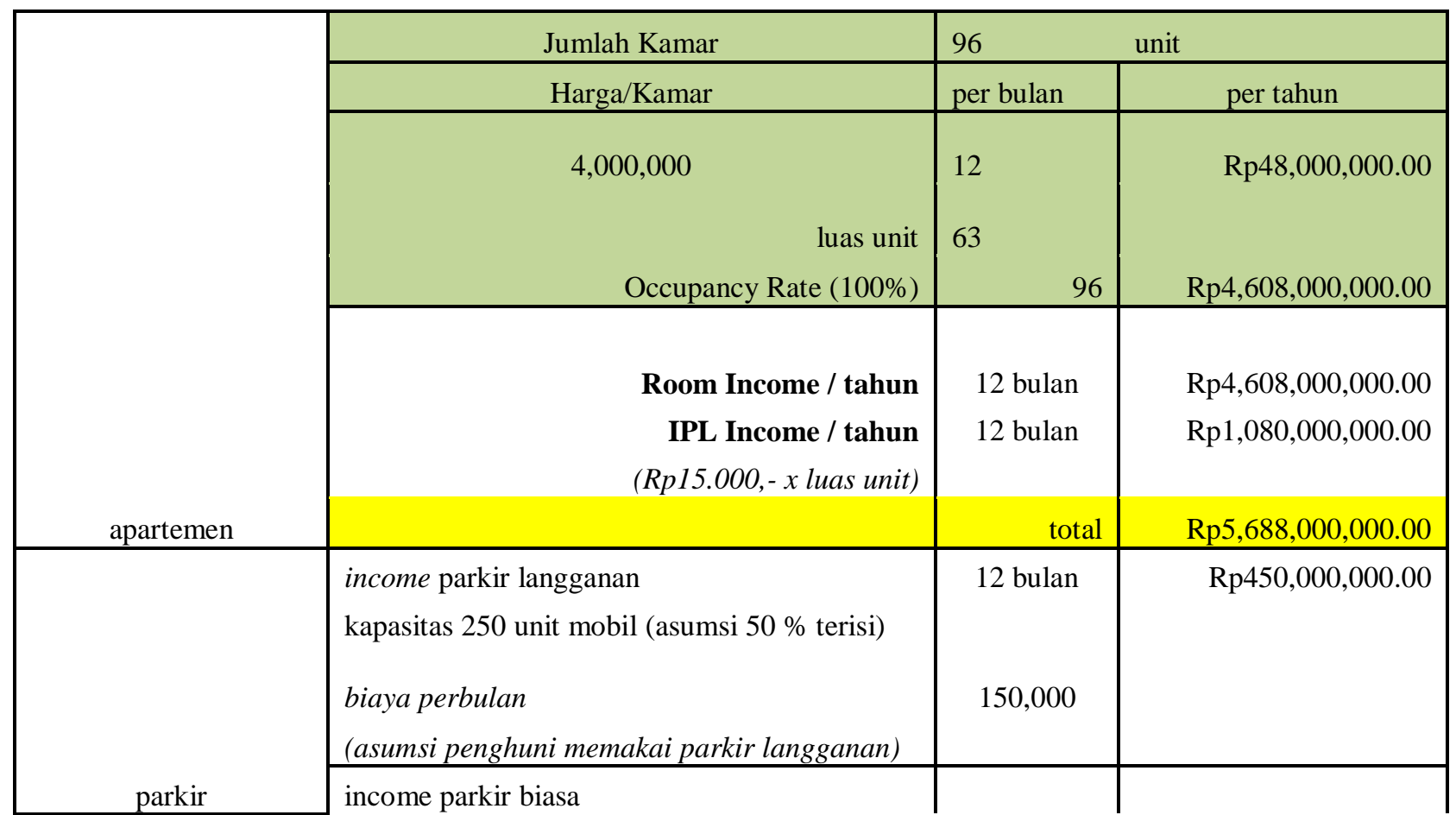




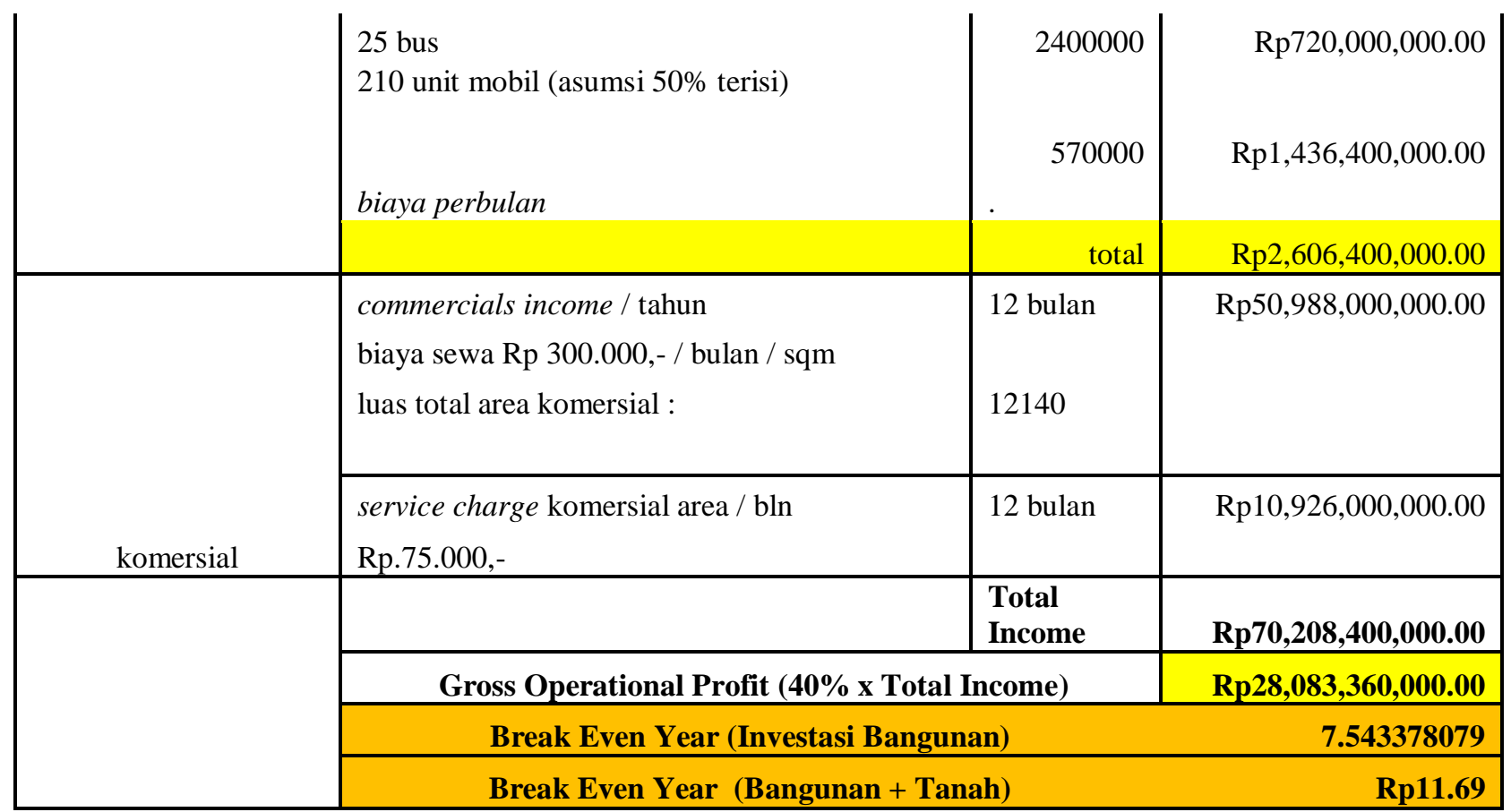

note rata - rata biaya sewa apartemen aeropolis perbulan = Rp. 2.200.000,-

Jika melihat perhitungan di atas, dengan penetapan harga :

- harga sewa unit apartemen per bulan Rp. 4.000.000,- disertai biaya IPL per meter persegi Rp $15.000,-$

- biaya parkir langganan per bulan Rp 150.000 ,- dan ongkos parkir per jamnya mengikuti harga standar

- harga sewa area komersial perbulan $\mathrm{Rp} 300.000,-$ per meter persegi disertai biaya maintenance IPL Rp 75.000,-

Maka investasi bangunan dan konstruksi akan balik modal ke investor / break event point di tahun ke 7 setelah bangunan beroperasional dengan asumsi occupancy rate untuk unit apartemen mencapai $75 \%$ dan gross profit $40 \%$ dan asumsi kapasitas parkir terisi $50 \%$.

Perhitungan NPV berdasarkan asumsi di atas

\begin{tabular}{|c|r|r|r|r|}
\hline Tahun ke & Cash Income Setelah Pajak & DF & $\mathbf{1 0 \%}$ & \multicolumn{1}{c|}{ Present Value Cash Income } \\
\hline 0 & - Rp211,843,427,000.00 & & 1.00 & - Rp211,843,427,000.00 \\
\hline 1 & $\mathrm{Rp} 70,208,400,000.00$ & & 0.91 & $\mathrm{Rp} 63,825,818,181.82$ \\
\hline 2 & $\mathrm{Rp} 70,208,400,000.00$ & & 0.83 & $\mathrm{Rp} 58,023,471,074.38$ \\
\hline 3 & $\mathrm{Rp} 70,208,400,000.00$ & & 0.75 & $\mathrm{Rp} 52,748,610,067.62$ \\
\hline 4 & $\mathrm{Rp} 70,208,400,000.00$ & & 0.68 & $\mathrm{Rp} 47,953,281,879.65$ \\
\hline 5 & $\mathrm{Rp} 70,208,400,000.00$ & & 0.62 & $\mathrm{Rp} 43,593,892,617.87$ \\
\hline 6 & $\mathrm{Rp} 70,208,400,000.00$ & & 0.56 & $\mathrm{Rp} 39,630,811,470.79$ \\
\hline 7 & $\mathrm{Rp} 70,208,400,000.00$ & & 0.51 & $\mathrm{Rp} 36,028,010,427.99$ \\
\hline 8 & $\mathrm{Rp} 70,208,400,000.00$ & & 0.47 & $\mathrm{Rp} 32,752,736,752.72$ \\
\hline
\end{tabular}




\begin{tabular}{|c|c|c|c|}
\hline 9 & Rp70,208,400,000.00 & 0.42 & Rp29,775,215,229.74 \\
\hline 10 & $\mathrm{Rp} 70,208,400,000.00$ & 0.39 & Rp27,068,377,481.58 \\
\hline \multicolumn{3}{|c|}{ TOTAL NPV } & Rp219,556,798,184.16 \\
\hline & & & Rp219,556,798,184.16 \\
\hline
\end{tabular}

NPV >0, dengan acuan cost of capital sebesar $10 \%$ (Cost of capital merupakan tingkat diskonto yang digunakan untuk mencapai return minimum yang diproyeksikan berdasarkan present value pada perhitungan NPV, cost of capital adalah tingkat pengembalian yang diharapkan dapat diperoleh dari dana yang ditanamkan dan COC merupakan target yang sudah ditentukan oleh perusahaan), maka proyek dapat dilaksanakan karena investasi yang akan dilaksanakan memberikan keuntungan bagi perusahaan .

Dengan usulan investasi awal untuk proyek $\mathrm{CBC}$ di lot 8 dan lot 9 sebesar Rp211,843,427,000.00. tanpa nilai sisa dan menghasilkan cash income per tahunnya sebesar Rp70,208,400,000.00 selama 7 tahun .

\section{KESIMPULAN DAN SARAN}

Setelah sempat melemahnya kondisi pasar properti di Indonesia, kini memasuki tahun 2018, kondisi tersebut belum juga menunjukkan pemulihan yang signifikan . Kondisi tersebut membuat para tim strategist / marketing planner masing - masing perusahaan developer untuk meluncurkan produknya dan program rencana keuangannya secara hati - hati. Namun ditengah lesunya pasar properti saat ini tidak menutup kemungkinan adanya kesempatan yang dapat dimanfaatkan untuk memperoleh keuntungan .

Dengan berbagai pertimbangan yang sudah disebutkan di atas, maka rencana lahan kosong di LOT 8 dan LOT 9 direncanakan pembangunan mixed use area dengan gabungan antara lofts apartemen - shuttle terminal - commercial zone tanpa adanya basement. Produk yang penulis ajukan untuk di launching terdiri dari:

\section{DATA RENCANA PRODUK YANG AKAN LAUNCHING}

\begin{tabular}{|c|c|c|c|c|}
\hline \multicolumn{5}{|c|}{ LOFTS APARTEMEN } \\
\hline NO & ITEM & $\begin{array}{c}\text { QTY } \\
\text { (UNIT) }\end{array}$ & LUAS PER UNIT & LUAS TOTAL \\
\hline 1 & APARTEMEN UNIT & 96 & 62.5 & 6000 \\
\hline 2 & PARKIR APARTEMEN & 500 cars & 12.5 & 6250 \\
\hline 3 & KOMERSIAL UNIT & 12 & 120 & 1440 \\
\hline \multicolumn{5}{|c|}{ SHUTTLE BUS TERMINAL } \\
\hline 1 & TERMINAL + LOUNGE (LEFT) & 1 & 675 & 675 \\
\hline 2 & TERMINAL + LOUNGE (RIGHT) & 1 & 4550 & 4550 \\
\hline \multicolumn{5}{|c|}{ COMMERCIALS ZONE } \\
\hline 1 & KOMERSIAL AREA & 20 & - & 5350 \\
\hline 2 & AREA PARKIR + SIRKULASI & $\begin{array}{l}420 \text { cars } \\
25 \text { buses }\end{array}$ & - & 5300 \\
\hline
\end{tabular}




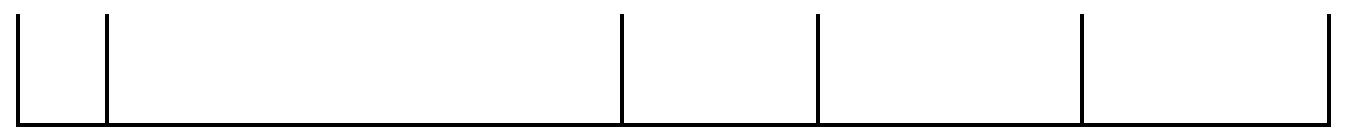

\section{Ucapan Terima Kasih (Acknowledgement)}

Peneliti mengucapkan terima kasih kepada segenap pihak yang memberikan kesempatan, kepercayaan dan dukungan penuh kepada peneliti untuk melaksanakan penelitian, dan selanjutnya dapat dilakukan penyusunan artikel.

\section{REFERENSI}

Adi, R., K. (2017). Manajemen Strategik. Tangerang: Pustaka Mandiri.

Bank Indonesia. (2016). Suku Bunga Dasar Kredit. Diperoleh November 2016. Dari http://www.bi.go.id/id/perbankan/suku-bunga-dasar/Default.aspx

Binus (2017) .Mengkaji kelayakan Bisnis Dengan Menggunakan Cost of Capital .Diperoleh dari http://accounting.binus.ac.id/2015/11/02/mengkaji-kelayakan-bisnis-menggunakan-costof-capital/

Ernest \& Neufert, P.. (2002). Architect Data (3rd edition). Oxford: The Alden Group.

Harian, Cara. (2017). Rumus NPV di Excel. Diperoleh 10 Juli 2017 dari http://caraharian.com/rumus-npv.html

Humphrey, Albert (December 2005). "SWOT Analysis for Management Consulting"(PDF). SRI Alumni Newsletter. SRI International.

Jannah, S., M. (2017). Banyak-kosong-tarif-sewa-gedung-perkantoran-di-jakarta-turun .Diperoleh 26 Juli 2017 .dari https://finance.detik.com/properti/d-3574492/banyak-kosongtarif-sewa-gedung-perkantoran-di-jakarta-turun.

Kasarda, J. D (2010). Airport City and The Aerotropolis: The Way Forward, Global Airport Cities.London: Insight Media.

Kasarda,J.D. (2011).Aerotropolis : The Way We Will Live Next ,New York : Farrar, Straus , and Giroux.

Kotler. P.(2016). Marketing Management. Boston: Pearson Education,Inc.

Laucereno,Sylke., Febrina. (2017). tren-sewa-kantor-turun-pengembang-beralih-ke-gudang .Diperoleh 2 Agustus 2017 dari https://finance.detik.com/properti/d-3583029/tren-sewakantor-turun-pengembang-beralih-ke-

gudang?_ga=2.268843057.1570435834.1520162380-511608283.1520162380

Liputan 6, Bisnis. (2018). Prediksi Properti di 2018. Diperoleh 5 Januari 2018 dari http://bisnis.liputan6.com/read/3215819/simak-prediksi-tren-bisnis-properti-di-2018.

Porter, M. E. (1980). Competitive Strategy: Techniques for Analyzing Industries and Competitors. New York: The Free Press.

Porter, M. E \& Maulana, A .(1996). Strategi Bersaing. Jakarta: Erlangga.

PrioritasLand. (2018). Booming Properti 2018. Diperoleh dari http://www.prioritaslandindonesia.com/news_detail.php?id_news=110................booming property 2018

PT SURYA TOTO INDONESIA TBK. (2017). Price List 2017. Jakarta.

Rapoport, Amos. "Tentang Asal - Usul Kebudayaan Pemukiman “. Pengantar Sejarah Perancangan Perkotaan. Bandung.n.d.hlm 22.

Rayanti, D. (2018). Ssaudi-bidik-investasi-properti-di-jakarta-bagaimana-potensinya? Diperoleh 15 Januari 2018 dari https://finance.detik.com/properti/d-3816053/saudi-bidik-investasiproperti-di-jakarta-bagaimana-potensinya?_ga=2.268843057.1570435834.1520162380511608283.1520162380 
Rayanti, D. (2018). Banyak Gedung Perkantoran di Jakarta Kosong. Diperoleh dari https://finance.detik.com/properti/3574427/waduh-banyak-gedung-perkantoran-di-jakartakosong

Simorangkir, Eduardo. (2017). penjualan-apartemen-di-jakarta-lesu?. Diperoleh 26 Juli 2017 dari https://finance.detik.com/properti/d-3575129/penjualan-apartemen-di-jakartalesu?_ga=2.92575965.1570435834.1520162380-511608283.1520162380

Simorangkir, Eduardo. (2018). Penyewaan-kantor-di-jakarta-diprediksi-naik-sepanjang-2018. Diperoleh 9 Januari 2018 dari https://finance.detik.com/properti/d-3805915/penyewaankantor-di-jakarta-diprediksi-naik-sepanjang-2018.

Sugianto,Danang. (2017). Tak-cuma-perkantoran-mal-di-jakarta-juga-banyak-kosong .Diperoleh 26 Juli 2017 dari https://finance.detik.com/properti/d-3574852/tak-cumaperkantoran-mal-di-jakarta-juga-banyak-kosong. 